\title{
Assessment of nutritional status and functional ability in the elderly
}

\section{Ocena stanu odżywienia i sprawności funkcjonalnej u osób w wieku podeszłym}

\author{
Magdalena Strugała ${ }^{1, A-D \oplus}{ }^{\oplus}$, Katarzyna Wieczorowska-Tobis ${ }^{2, C, E \oplus}{ }^{\text {, Dorota Talarska }}{ }^{1, \mathrm{E}-\mathrm{F} \oplus}$ \\ ${ }^{1}$ Chair and Department of Health Prevention, University of Medical Sciences, Poznan, Poland \\ ${ }^{2}$ Chair and Clinic of Palliative Medicine, University of Medical Sciences, Poznan, Poland \\ A - Koncepcja i projekt badania, B - Gromadzenie i/lub zestawianie danych, C - Analiza i interpretacja danych, \\ $D$ - Napisanie artykułu, E - Krytyczne zrecenzowanie artykułu, F - Zatwierdzenie ostatecznej wersji artykułu
}

Strugała M, Wieczorowska-Tobis K, Talarska D. Assessment of nutritional status and functional ability in the elderly. Med Og Nauk Zdr. 2019; 25(4): 274-281. doi: $10.26444 / \mathrm{monz} / 114445$

\section{Abstract}

Introduction and objective. The incidence of problems related with nutrition disorders and decrease of functional activity among the elderly are often an important element of their disability. The aim of the study was to analyse the relationship between the nutritional status and functional fitness of aselected population of elderly people.

Materials and method. The cross-sectional study comprised 412 elderly persons, including 318 females (77\%). The mean age of the study group was 75.8 years \pm 7.6 . Within the entire group an analysis of correlation between nutritional status and functional ability was performed, assessed according to the Mini Nutritional Assessment (MNA) scale, as well as social and demographic parameters, health condition (number of chronic diseases, drugs taken) and the functional independence exponents. To identify factors significantly affecting the risk of malnutrition, the logistic regression model was used. Results obtained were presented as odds ratios with $95 \%$ confidence intervals. A stepwise multiple logistic regression with backward elimination was also performed.

Results The normal nutritional status (MNA 23-30 point), good mental status (MMSE 24-30), no risk of depression (GDS - 0-5 points), risk of falls (TUG - less than 14 seconds) and correct functional capability (Barthel index 86-100; IADL - 27), were determined in 253 (61.4\%) respondents. Multi-parameter analysis proved that the independent determinants of nutrition status were: risk of depression $(p<0.001)$, risk of falling $(p<0.01)$, cognitive ability $(p<0.05)$ and education $(p<0.05)$.

Conclusions Incorrect nutritional status can be both a consequence and cause of disability. Due to the determined correlation between nutritional status and the components of functional fitness, the existence of irregularities in the area of any element should necessitate the conduction of screening tests to determine nutritional status.

\section{Key words}

malnutrition, functional capability, elderly

Address for correspondence: Magdalena Strugała, Chair and Department of Health Prevention, Poznan University of Medical Sciences

E-mail: magdastrugal@onet.eu

Received: 13.09.2019; Accepted: 20.11.2019; published online: 3.12.2019

\section{- Streszczenie}

Wprowadzenie. Problemy związane z zaburzeniami stanu odżywienia przyczyniają się do wzrostu chorobowości osób starszych i wraz ze spadkiem aktywności funkcjonalnej stanowią często ważny element niesprawności.

Celem podjętych badań była analiza związku pomiędzy stanem odżywienia a sprawnością funkcjonalną u osób w wieku podeszłym.

Materiał i metoda. Badaniem przekrojowym objęto 412 osób starszych, w tym 318 kobiet (77\%). Średni wiek pacjentów w badanej grupie wynosił 75,8 $\pm 7,6$ lat. W obrębie całej grupy przeprowadzono analizę korelacji między stanem odżywiania, ocenianym według skali MNA (Mini Nutritional Assessment), a parametrami społecznymi i demograficznymi, stanem zdrowia (liczba chorób przewlekłych, przyjmowanych leków) oraz wykładnikami sprawności funkcjonalnej. Aby zidentyfikować czynniki istotnie wpływające na ryzyko niedożywienia, zastosowano model regresji logistycznej. Uzyskane wyniki przedstawiono jako iloraz szans z 95-proc. przedziałami ufności. Przeprowadzono również stopniową regresję logistyczną z eliminacją wsteczną.

Wyniki. Prawidłowy stan odżywienia (MNA 23-30 pkt), dobry stan psychiczny (MMSE 24-30), brak ryzyka depresji (GDS - 0-5 pkt) i upadków (TUG - mniej niż 14 s) oraz poprawną sprawność funkcjonalną (wskaźnik Barthel 86-100; IADL - 27) określono u $253(61,4 \%)$ respondentów. Przeprowadzenie analizy wieloparametrowej wykazało, że niezależnymi determinantami stanu odżywiania były: ryzyko depresji $(p<0,001)$, ryzyko upadku $(p<0,01)$, sprawność poznawcza $(p<0,05)$ oraz wykształcenie $(p<0,05)$.

Wnioski. Nieprawidłowy stan odżywienia może być zarówno konsekwencją, jak i przyczyną niepełnosprawności. Ze względu na ustaloną korelację między stanem odżywienia a składnikami sprawności funkcjonalnej występowanie nieprawidłowości w obszarze dowolnego elementu wydolności funkcjonalnej powinno zobowiązać do przeprowadzenia badań przesiewowych stanu odżywienia.

\section{Słowa kluczowe \\ niedożywienie, sprawność funkcjonalna, ludzie starsi}

\section{Abbreviations}

MNA - Mini Nutritional Assessment scale; MMSE - Mini Mental State Examination; Barthel Index - Barthel Index of Activities of Daily Living; IADL - Instrumental Activities of Daily Living Scale; GDS - Geriatric Depression Scale; TUG - Time Up and Go. 


\section{INTRODUCTION}

Problems with nutritional status can impact functional ability. Problems associated with nutritional status impairment constitute one of the vital prognostic factors concerning the incidence of functional ability limitations in the elderly population $[1,2]$. In particular, the issue of physical disability among the elderly remains crucial, since along with the age it constitutes the most significant prognostic factor of mortality [3]. The risk of functional disability increases with the gradual decrease in the organ and systems' functional reserve, whereas age-related physiological changes, especially in connection with other social, economic and psychological factors, as well as with diseases, may predispose patients to protein-energetic malnutrition [2,3]. Malnutrition (according to the scale MNA below 17 points) causes a compromised immune system, increases the risk of infections, delays wound healing, and leads to a progressive worsening of the clinical conditions of older people. Deterioration of the nutritional status in the elderly appears to be a quick process and difficult to reverse; advanced malnutrition is more difficult to correct in the elderly than in the young. The most important etiological factors contributing to malnutrition in the elderly are numerous somatic [4] and mental disorders (dementia and depression) $[5,6]$, administered medications, self-care incapacity [7], as well as improper diet and poor condition of the oral cavity (xerostomy) [8], poverty, loneliness and social contact limitation [9]. In addition, the role of C-reactive protein (CRP) as a risk factor in the development of malnutrition in the elderly, is frequently stressed. However, CRP is not an indicator of nutrition status, but may be a predictor of potential nutrition problems. CRP almost instantly reflects the catabolic state of the body; in fact, due to the association between nitrogen balance and an increase in the body's catabolic state, it may constitute an indirect indicator of the nutritional status [10].

Nutritional status impairment, especially as malnutrition combined with the progressive aging process, directly correlates with the increase in morbidity and mortality [4]. Furthermore, it leads to decreased immune reactions and ineffective treatment response, increases the risk of complications and prolongs hospitalization, thus increasing the cost of hospital care and treatment [11]. Additionally, it encompasses numerous serious consequences, such as functional disability [6]. Unintentional body mass loss, an increase in sarcopenia due to aging, which leads to physical activity limitation and an increased risk of falling frequently ending with fractures, constitute just a few of the threats to physical ability which consequently lead to the immobility syndrome [12].

Another vital consequence concerns changes in whole body protein synthesis and catabolism, protein synthesis decrease in the liver, where hyperproteinaemia accompanied by immune function impairment, increase the risk of infection complications. In addition, respiratory system impairment, including weakening of the respiratory muscles and atrophy, causes lung ventilation deterioration leading to pneumonia.

Finally, the following aspects should be stressed as possible consequences of the immobility syndrome: circulatory system dysfunction combined with the concomitant deficiency anaemia (which may lead to central nervous system impairment and cause cognitive function impairment), decrease in liver and pancreas function, as well as inhibition of peristaltic movements which, as a consequence, disrupt the digestive and absorption processes, thus deteriorating the already existing state of malnutrition $[13,14]$.

Although the risk of malnutrition and malnutrition itself is recognized in the scientific world, in Poland it still remains underassessed and frequently undiagnosed. Virtually no data exists in the Polish literature about nutritional status impairment among the elderly in terms of their functional ability. Therefore, the presented study attempts to supplement the above-mentioned scarce data.

The diagnosis and treatment of malnutrition constitute the key steps in the caring process for the elderly patients [15]. Untreated malnutrition leads to increased dependence on other members of society and the necessity for institutionalization. However, there is no universal method or ready-made screening tests for diagnosis of the nutritional state in the elderly, which has the sensitivity and specificity appropriate for the identification of the patients in the group at risk. Therefore, a combination of various methods is necessary, such as a precise nutritional interview, anthropometric tests, including establishing body mass, a body composition test, selected haematological and biochemical parameters (concentration levels of albumin, creatinine, cholesterol, inflammation markers including CRP), combined with an established screening tool, such as the Mini Nutritional Assessment (MNA) scale.

Therapy for the elderly at risk of malnutrition, as well as with malnutrition itself, should be aimed at improvement of the mental mood, treatment of any infection and inflammation, modifying medications negatively influencing the appetite, balancing metabolic and fluid-electrolyte imbalance, and most of all, proper protein-energetic supplementation, as well as a reasonable dose of daily physical activity [15].

\section{OBJECTIVE}

The main objectives of the presented study were:

1. evaluation of the nutritional status and degree of independence of older adults;

2. determination of the effect of functional condition, demographic and social factors on the risk of malnutrition and disability in the study group;

3. identification of the factors to be taken into consideration when planning disability prevention in the study group;

4. to prove suitability of the MNA questionnaire in evaluation of the risk of malnutrition.

\section{MATERIALS AND METHOD}

Screening examination aimed at assessing the current nutritional status, and at a subsequent evaluation of the association between nutritional status and functional ability in a given population of the elderly. On the basis of the presented risk factors, possible determinants influencing the deterioration of the nutritional status and a decrease in functional ability will be demonstrated.

Study organization. The study was conducted for 12 months in three senior centres: 204 permanent residents of a Nursing Home (NH - 49.6\%), 104 residents of Day Care Centres 
(DCC - 25.2\%), and 104 students of the University of the Third Age (UTA - 25.2\%) in Poznań, Poland. The collected questionnaires helped them learn more about the barriers in the independent functioning of older adults. During this time, the study included 482 older adults. 70 senior citizens withdrew from the study, and 6 questionnaires were not completely filled in and were not included in the analysis. Eventually, the analysis was based on 412 questionnaires.

The research group included 318 (77.2\%) women and 94 (22.8\%) men, aged above 65 (65-100 years). Prior to filling in the questionnaire, the researcher explained the study and discussed the tools used. Senior citizens could use the assistance researchers when filling in the questionnaire, or withdraw from the study at any time throughout its duration.

The following criteria were established:

- age: $\geq 65$;

- a somatic state allowing for extensive examination involving the selected scales;

- mental ability allowing filling-in the questionnaire: Mini Mental State Examination (MMSE) > 10;

- resident of Poznań or its vicinity;

- consent to participate in the study.

Research tools. General personal and socio-economic data regarding health condition, chronic diseases and administered medications were collected on the basis of a short interview, based on a carefully formulated questionnaire.

Study tools. The Barthel Index was used to assess functional ability regarding basic daily activities on a scale of $0-100$ points. Patients with a score above 86 are in good functional condition, while a score below 20 means severe impairment $[16,17]$.

1. Instrumental Activities of Daily Living Scale (IADL) - the version with 9 questions, with 3 options of answers was used: 1 point - full dependence, 2 points - partial dependence, and 3 - independence. Maximum total score - 27 points [17].

2. Mini-Mental State Examination (MMSE) was used to evaluate cognitive abilities [18], scoring range $0-30$ points. A score of 11-19 meant moderate mental impairment, 20-13 light cognitive impairment, and 0-10 - severe mental impairment. Normal mental abilities were within the score range 24-30. Each test started with an evaluation of the person's cognitive abilities using the MMSE scale, and only persons with a score of at least 10 were included in the subsequent stages of the study.

3. The Time Up and Go (TUG) test was used in the risk of falls assessment. Time Up and Go (TUG) is a gait fluency assessment over a distance of 3 meters. It measures the time of: getting up from a chair, walking the distance of $3 \mathrm{~m}$, turning $180^{\circ}$, returning and sitting again. Older adults performed this test twice, and the best result is then analyzed. Risk of falls occurs if more than $12 \mathrm{~s}$ are required to complete these tasks. For statistical purposes, the following classification was adopted: steady and fast gait, unsteady and fast gait, steady and slow gait, unsteady and slow gait [19].

4. Geriatric Depression Scale (GDS) - used for Comprehensive Geriatric Assessment [20] and assists with the diagnosis of depression in elderly people. Scoring range: $0-15$. Score of $0-5$ - no depression, 6-10 - moderate depression, and 11-15 - severe depression.
5. The full version of Mini Nutritional Assessment scale (MNA) [21] was used in the research for nutritional status assessment. The purpose of this tool is to detect malnutrition or risk of malnutrition development in the elderly. Scoring range: $0-30$. Score of 24-30 - no malnutrition, 17-23.5 - risk of malnutrition, and less than 17 points severe malnutrition.

Thus, nutritional interview and subjective nutritional status assessment was performed only in patients who obtained more than 19 points in the MMSE test.

In the course of the research the following stages were covered:

- during stage 1 an interview was performed in order to obtain socio-demographic and health data;

- anthropometric measurements were taken;

- nutritional status assessment established;

- functional ability evaluated.

Subsequently, analysis was performed of the dependence between nutritional status according to the MNA scale and socio-demographic parameters, general health condition (including chronic diseases, administered medications), and functional ability indicators.

Due to the small group of patients suffering from malnutrition (23 subjects, $5.6 \%$ of the total research group), in order to further analyze the nutritional status and functional ability association, the MNA scale score was assessed in 2 categories: subjects with proper nutritional status, and patients with poor nutritional status.

The study was approved by the Medical Sciences Ethical Board at Poznan University. All patients were informed about the methods and purpose of the study and gave informed consent to participate.

Statistical analysis. The obtained data was introduced to the Excel database specially devised for the purpose of the research, whereas all the calculations were performed with StatSoft Statistica 8.0. First, normality of distribution was checked using the Shapiro-Wilk test. Due to the lack of normality of distribution in some data, the median and range were involved separately from mean values and standard deviation. Mann-Whitney test was employed to compare 2 variables, whereas Kruskal-Wallis test was used to compare more than 2 variables. If the Kruskal-Wallis test indicated substantial differences between the variables, Dunn's post hoc test was employed. In order to assess the dependence between the variables, Spearman rank correlation coefficient was used. The positive result frequency in the analyzed groups was compared by means of Chi square test or Fisher's test, depending on the size of the analyzed group. Logistic regression was used to assess the simultaneous dependence among numerous variables, presenting the odds ratio and confidence interval with the borderline of $95 \%$. The obtained analysis results were statistically relevant with $\mathrm{p}<0.05$, and the results presented as mean $\pm \mathrm{SD}$.

Study group characteristics. The study included 412 subjects aged above 65 (65-100 years). Of these, 318 (77.2\%) were female and $94(22.8 \%)$ male. The mean age of the subjects was 75.8 years $( \pm 7.6$, median 75.5$)$. The majority of the subjects did not reside with their families (306, 74.0\%). 


\section{RESULTS}

The study started with evaluation of the participants' cognitive abilities using MMSE screening tool. Average score attained $-24.4 \pm 4.7$, median 26.0. In terms of the basic activities of daily living (Barthel Index), the subjects scored from 11-100; mean score: $92.1 \pm 15.4$, median 100 . Severe impairment was found in nearly $16 \%$ of the group ( 66 respondents). In terms of complex activities of daily living (IADL), the subjects scored from 9-27; mean score: $21.7 \pm 5.5$, median 24.0. GDS - 34.5\% (142 respondents); mean score: $4.9 \pm 3.3$, median 4.0. Moderate depression (17 respondents); severe depression - 4.1\%. 253 (64.4\%) had no depression. Gait fluency evaluated in TUG scale found slow and unsteady gait and risk of falls in 53 (13.0\%) of the subjects.

Nutritional status in the study group was assessed using the MNA questionnaire, recognised in Poland as a good tool for the evaluation. Average MNA Score (7.5-30.0) of the study group $-23.4 \pm 3.7$, median $-24.0,188$ subjects $(45.6 \%)$ were at risk of malnutrition or malnutrition - 17.5-23.0 points. The subjects were taking from $0-13$ medicines, on average $4.1 \pm 3.0$ per day. Table 1 shows detailed socio-demographic and health condition data, as well as nutritional status and functional ability of the subject group.
Risk of malnutrition and disability - statistical analysis. The average score according the MNA scale was 23.4 \pm 3.7 , which indicated that a standard patient was on the verge of malnutrition. Statistical analysis revealed an association between nutritional status and variables, such as: age $\left(r^{2}=0,06\right.$; $\mathrm{p}<0.001)$ - average score on the MNA scale decreased with age $\left(r^{2}=0,06 ; p<0.01\right)$, education $\left(r^{2}=0,08 ; p<0.001\right)-$ the better education the higher MNA scale score, income $\left(r^{2}=0,06 ; p<0,001\right)$ - the higher, the better the nutritional status. Nutritional status improved with a decreased amount of administered medications in the daily system $\left(r^{2}=0.04\right.$; $\mathrm{p}<0.001)$ - the more medications, the worse the MNA scale score; however, there was no association with the number of chronic diseases $(\mathrm{p}=0.168)$. In the subjects taking up to 4 medications daily, the appropriate nutritional status was substantially more frequent, i.e. in 123 patients (59\%). In the group taking more than 4 medications daily, 77 patients (46\%) showed appropriate nutritional status. No correlation was found between nutritional status assessment and gender or marital status $(\mathrm{p}=0.397$ and $\mathrm{p}=0.0591$, respectively). Crucial correlations were established between nutritional status and all functional ability elements.

Table 1. The socio-demographic characteristics, health condition, nutrition status and physical function

\begin{tabular}{|c|c|c|c|c|}
\hline Variables & Day Care Centres and University of Third Age & Nursing Home & Total & P-value* \\
\hline \multicolumn{5}{|c|}{ Socio-demographic data } \\
\hline Sex & $\begin{array}{l}\text { Female: } 183(87.9 \%) \\
\text { Male: } 25(12.1 \%)\end{array}$ & $\begin{array}{l}\text { Female: } 135(54.9 \%) \\
\text { Male: } 69(45.1 \%)\end{array}$ & $\begin{array}{c}\text { Female: } 318(77.2 \%) \\
\text { Male: } 94(22.8 \%)\end{array}$ & $p<0.05$ \\
\hline \multicolumn{5}{|l|}{ Age } \\
\hline mean $\pm S D$ & $72.8 \pm 6.0$ & $78.8 \pm 6.5$ & $75.8 \pm 7.6$ & \multirow{5}{*}{$\mathrm{p}<0.001$} \\
\hline median & 72.2 & 79.0 & 75.5 & \\
\hline range & $65-99$ & $65-100$ & $65-100$ & \\
\hline $65-74$ years of age & $126(60.6 \%)$ & $64(31.4 \%)$ & $190(46.1 \%)$ & \\
\hline over 75 years of age & $81(38.9 \%)$ & $141(61.1 \%)$ & $222(53.9 \%)$ & \\
\hline \multicolumn{5}{|l|}{ Marital status } \\
\hline single & $154(74.0 \%)$ & $152(74.5 \%)$ & $306(74.0 \%)$ & \multirow[t]{2}{*}{$p=0.095$} \\
\hline in a relationship & $54(26.0 \%)$ & $52(25.5 \%)$ & $106(26.0 \%)$ & \\
\hline \multicolumn{5}{|l|}{ Education } \\
\hline university & $61(29.3 \%)$ & $19(9.4 \%)$ & $80(19.5 \%)$ & \multirow{3}{*}{$\mathrm{p}<0.001$} \\
\hline vocational & $14(6.7 \%)$ & $27(13.2 \%)$ & $41(9.9 \%)$ & \\
\hline primary & 31 (14.9\%) & $85(41.6 \%)$ & $116(28.1 \%)$ & \\
\hline \multicolumn{5}{|l|}{ Monthly income** } \\
\hline up to 1000 PLN & $57(27.4 \%)$ & 55 (53.4\%) & $112(36.0 \%)$ & \multirow{3}{*}{$\mathrm{p}<0.01$} \\
\hline 1001-1500PLN & 96 (46.2\%) & 39 (37.9\%) & $135(44.0 \%)$ & \\
\hline more than 1500PLN & $55(26.4 \%)$ & $9(8.7 \%)$ & $64(20.0 \%)$ & \\
\hline
\end{tabular}

\begin{tabular}{|c|c|c|c|c|}
\hline \multicolumn{5}{|c|}{ Health condition } \\
\hline Chronic diseases & & & & \multirow{6}{*}{$\mathrm{p}<0.01$} \\
\hline mean $\pm S D$ & $2,2 \pm 1.4$ & $3,0 \pm 1.3$ & $2.3 \pm 1.3$ & \\
\hline median & 2,0 & 3.0 & 2.0 & \\
\hline range & $0-6.0$ & $1-7,0$ & $0-7$ & \\
\hline more than 3 & $20(9.6 \%)$ & $43(21.2 \%)$ & $63(15.3 \%)$ & \\
\hline 1-3 diseases & $169(81.2 \%)$ & $155(75.9 \%)$ & $324(78.6 \%)$ & \\
\hline \multicolumn{5}{|l|}{ Number of medications } \\
\hline mean $\pm S D$ & $3,3 \pm 2.7$ & $7,1 \pm 2.6$ & $4,1 \pm 3.0$ & \multirow{6}{*}{$p<0.001$} \\
\hline median & 3.0 & 7.0 & 4.0 & \\
\hline range & $0-12.0$ & $0-13.0$ & $0,0-13.0$ & \\
\hline more than 4 & $37(17.8 \%)$ & $128(62.7 \%)$ & 165 (41.0\%) & \\
\hline 1-4 medications & $145(69.7 \%)$ & $69(33.8 \%)$ & $214(51.0 \%)$ & \\
\hline no medications & $26(12.5 \%)$ & $7(3.5 \%)$ & $33(8.0 \%)$ & \\
\hline
\end{tabular}


Table 1. The socio-demographic characteristics, health condition, nutrition status and physical function - continuation

\begin{tabular}{|c|c|c|c|c|}
\hline Variables & Day Care Centres and University of Third Age & Nursing Home & Total & P-value* \\
\hline \multicolumn{5}{|c|}{ Nutrition status } \\
\hline mean $\pm S D$ & $24.8 \pm 2.9$ & $21.9 \pm 3.8$ & $23.4 \pm 3.7$ & \multirow{4}{*}{$\mathrm{p}<0.001$} \\
\hline median & 25.5 & 22.5 & 24.0 & \\
\hline range & $13.7-29.5$ & $8.2-28.2$ & $7.5-30.0$ & \\
\hline normal & $146(71.6 \%)$ & $78(37.5 \%)$ & $224(54.4 \%)$ & \\
\hline \multicolumn{5}{|c|}{ Functional ability } \\
\hline \multicolumn{5}{|l|}{ MMSE** } \\
\hline mean $\pm S D$ & $26.1 \pm 3.7$ & $25.1 \pm 3.7$ & $24.4 \pm 4.7$ & \multirow{5}{*}{$\mathrm{p}<0.01$} \\
\hline median & 27.5 & 25.0 & 26.0 & \\
\hline range & $14-30.0$ & $12.5-30.0$ & $11.0-30.0$ & \\
\hline moderate dementia & $34(16.6 \%)$ & $6(5.7 \%)$ & 40 (13.0\%) & \\
\hline normal & $122(59.5 \%)$ & $84(80.0 \%)$ & $206(66.0 \%)$ & \\
\hline \multicolumn{5}{|l|}{ GDS } \\
\hline mean $\pm S D$ & $5,2 \pm 2.9$ & $5.2 \pm 2.9$ & $4.9 \pm 3,3$ & \multirow{6}{*}{$\mathrm{p}<0.05$} \\
\hline median & 4.0 & 5.0 & 4.0 & \\
\hline range & $0-13.0$ & $0-13.0$ & $0.0-15.0$ & \\
\hline severe depression & $5(2.4 \%)$ & $12(5.8 \%)$ & $17(4.1 \%)$ & \\
\hline moderate depression & $61(29.3 \%)$ & $81(39.7 \%)$ & $142(34.5 \%)$ & \\
\hline no depression & $142(68.3 \%)$ & $111(54.5 \%)$ & $253(64.4 \%)$ & \\
\hline \multicolumn{5}{|l|}{ Barthel } \\
\hline mean $\pm S D$ & $96.3 \pm 6,4$ & $89.2 \pm 15.9$ & $92.1 \pm 15.4$ & \multirow{6}{*}{$\mathrm{p}<0.01$} \\
\hline median & 100.0 & 95.0 & 100.0 & \\
\hline range & $60-100.0$ & $35-100.0$ & $11-100.0$ & \\
\hline decreased ability & $0.0(0.0 \%)$ & $2(1.0 \%)$ & $2.0(0.5 \%)$ & \\
\hline disability & $8(3.8 \%)$ & $58(28.4 \%)$ & $66(16.0 \%)$ & \\
\hline good condition & $200(96.2 \%)$ & $144(70.6 \%)$ & $344(83.0 \%)$ & \\
\hline \multicolumn{5}{|l|}{ IADL } \\
\hline range & $12.0-27.0$ & $9.0-27.0$ & $9.0-27.0$ & \multirow{3}{*}{$p<0.001$} \\
\hline requires assistance & 106 (50.9\%) & $200(98.0 \%)$ & $306(75.0 \%)$ & \\
\hline full ability & $102(49.1 \%)$ & $4(2.0 \%)$ & $106(25.0 \%)$ & \\
\hline \multicolumn{5}{|l|}{ Up and Go } \\
\hline mean $\pm S D$ & $6.7 \pm 4.0$ & $12.9 \pm 10,0$ & $9.3 \pm 8.2$ & \multirow{5}{*}{$p<0.001$} \\
\hline median & 6.0 & 9.6 & 7.1 & \\
\hline range & $2.0-30.0$ & $2.8-57.0$ & $2.0-101.0$ & \\
\hline risk of falls & $8(3.8 \%)$ & $45(22.0 \%)$ & $53(13.0 \%)$ & \\
\hline no risk of falls & 200 (96.2\%) & $159(88.0 \%)$ & 359 (87.0\%) & \\
\hline
\end{tabular}

*Chi-Square test ${ }^{* *}$ fewer subjects taking part in the research

Nutritional status and cognitive functions abilities. 119 patients (58\%) presented appropriate cognitive ability and normal nutritional status. In addition, 20 subjects (31\%) showed mild dementia and good nutritional status; however, only one patient presented with appropriate nutritional status in the group with moderate dementia. Furthermore, the majority of subjects with an appropriate MMSE score were characterized by appropriate nutritional status $(\mathrm{p}<0.001)$. In contrast to the subjects with an MMSE score below the threshold of dementia, the score corresponding to both mild and moderate dementia was more frequent in patients with malnutrition or at the risk of malnutrition $(\mathrm{p}<0.0001)$. Additionally, a positive correlation was observed between the MMSE scale score and the MNA scale, both in subjects living in their own environment and in institutions. Therefore, subjects presenting better cognitive functions also presented a better nutritional status $\left(\mathrm{r}^{2}=0.14 ; \mathrm{p}<0,001\right)$ (Fig. 1).

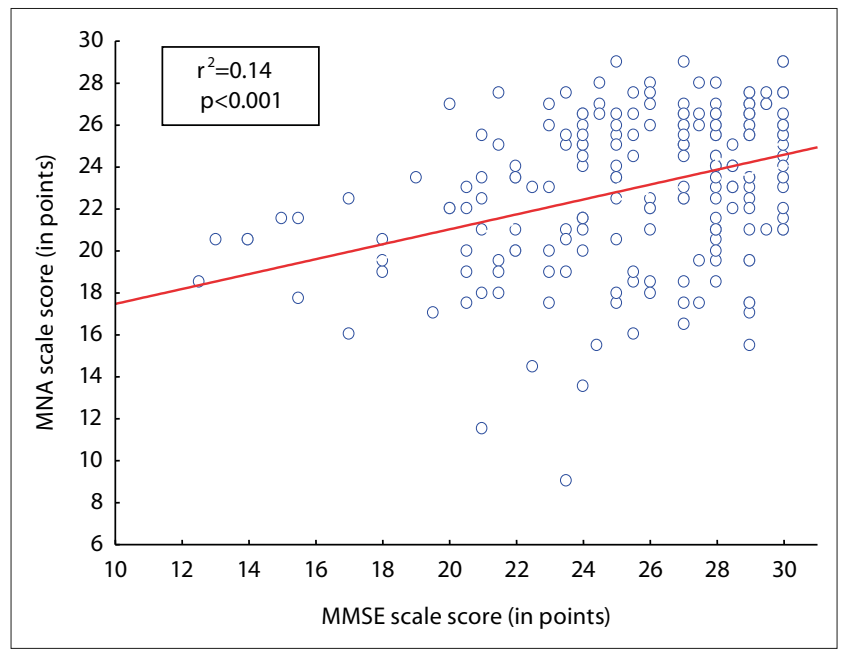

Figure 1. Association between cognitive functions efficiency according to the MMSE scale and the nutritional status according to the MNA scale 
Nutritional status and depression. In the group of 170 patients (73\%) presenting normal nutritional status and lack of depression, 52 subjects (44\%) showed moderate depression, whereas severe depression was found in 2 patients (12\%). Additionally, patients with a good GDS score indicating lack of depression were characterized by normal nutritional status $(\mathrm{p}<0.001)$. The result indicating both moderate and severe depression was more frequent in subjects with malnutrition or at the risk of malnutrition $(\mathrm{p}<0.001)$. A statistically crucial correlation was observed in all subjects between the GDS scale score indicating the risk of depression or its presence, and the MNA scale scores. Hence, patients with lowered depression risk showed better nutritional status $\left(r^{2}=21\right.$; $\mathrm{p}<0.001$ ) (Fig. 2).

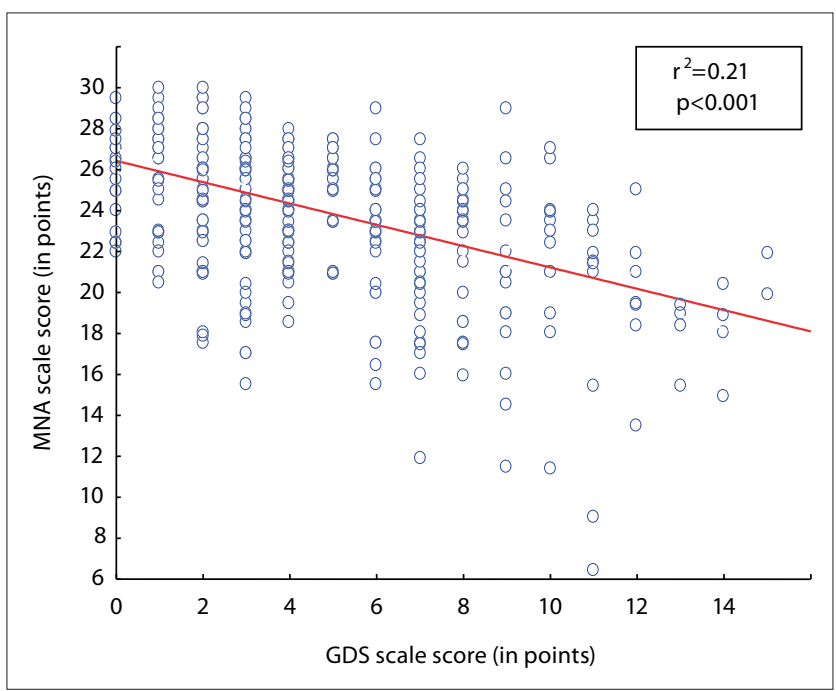

Figure 2. Association between the mood assessment according to the GDS scale, and the nutritional status in the MNA scale

Nutritional status and self-care capacity. Appropriate nutritional status and full self-care capacity was presented in 210 subjects (61\%), whereas a decrease in capability was shown in 14 patients (21\%). In 2 incapable subjects $(0.5 \%)$ a risk of malnutrition was revealed. In the course of analysis between the achieved results in the Barthel and MNA scale, a strong positive correlation was found only in institutionalized subjects, i.e. patients in institutions presented with better functional state, as well as with better nutritional status $(\mathrm{p}<0,001)$ (Fig. 3).

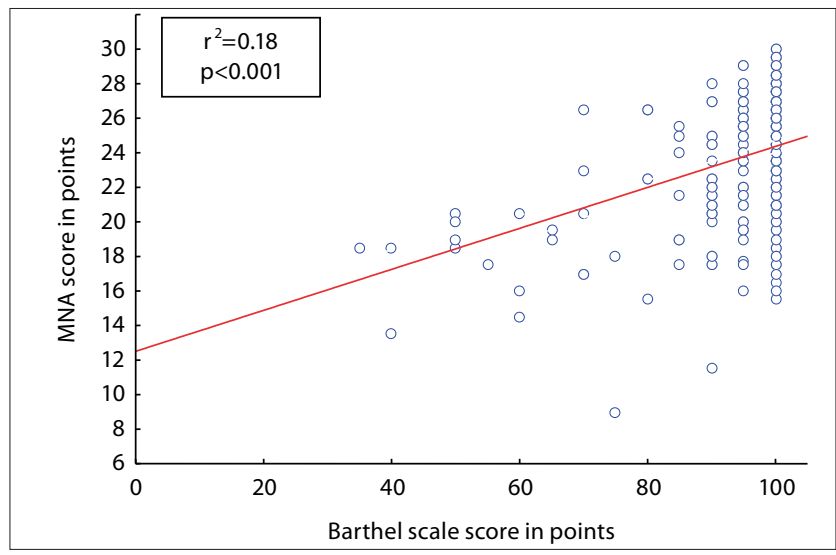

Figure 3. A correlation between self-care capacity in basic daily activities in Barthel scale and a nutritional status in the MNA scale
Nutritional status and self-care capacity in complex daily activities. 84 patients (79\%) were fully independent with normal nutritional status, whereas 140 subjects (46\%) presented normal nutritional status and required assistance. A positive correlation was shown between the subjects' results in the IADL scale and in the MNA scale, both in terms of patients living in their own environment and in institutions. Thus, patients who showed more capability in terms of complex daily activities presented also better nutritional status $\left(\mathrm{r}^{2}=0,26 ; \mathrm{p}<0,001\right)$, (Fig. 4$)$.

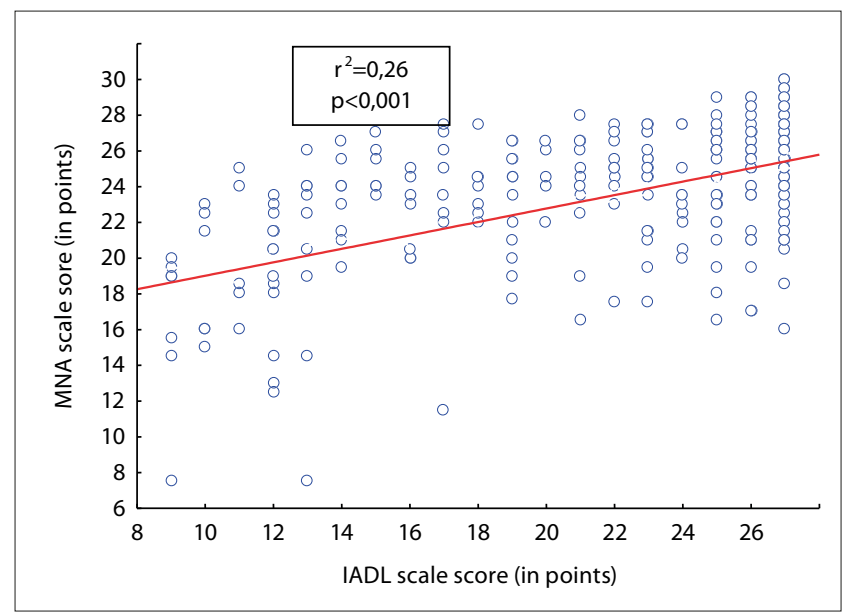

Figure 4. The association between self-care capacity in complex daily activities in the IADL scale and the nutritional status according to the MNA scale

Nutritional status and the risk of falls. 213 patients (59\%) presented normal nutritional status and risk of falls absence, risk of falls was present in 11 patients (22\%). What is more, patients with better nutritional status more frequently had better scores in the risk of falls test $(\mathrm{p}<0,001)$. Even though it was established that an average subject did not experience an increased risk of falls, the test result was poorer in the MNA scale $\left(\mathrm{r}^{2}=0,14, \mathrm{p}<0,001\right)$ with the increased test completion time. Nutritional status and functional ability indicators (Table 2.), (Fig. 5).

Table 2. Association between functional ability efficiency and the nutritional status according to the MNA scale

\begin{tabular}{lll}
\hline Functional ability & \multicolumn{2}{c}{$\begin{array}{c}\text { Mini nutritional } \\
\text { assessment }- \text { MNA }\end{array}$} \\
\cline { 2 - 4 } & $\begin{array}{c}\mathrm{r}^{2} \text { (Sperman } \\
\text { rank } \\
\text { correlation) }\end{array}$ & $P$-value* \\
\hline cognitive functions to the MMSE test & $\mathrm{r}^{2}=0.14$ & $\mathrm{p}<0.001$ \\
\hline mood assessment according to the GDS scale & $\mathrm{r}^{2}=0.21$ & $\mathrm{p}<0.001$ \\
\hline self-care capacity in basic daily activities in Barthel scale & $\mathrm{r}^{2}=0.18$ & $\mathrm{p}<0.001$ \\
\hline self-care capacity in complex daily activities in the IADL & $\mathrm{r}^{2}=0.18$ & $\mathrm{p}<0.001$ \\
scale & $\mathrm{r}^{2}=0.18$ & $\mathrm{p}<0.001$ \\
\hline the risk of falls according to the Timed Up and Go test & &
\end{tabular}

Mulitparameter analysis. As a result of a mulitparameter analysis it was indicated that the risk of depression was the strongest determinant of nutritional state (OR 0.9; 95\% CL 0.02-0.35), then risk of falls (OR 0.0; 95\% CL 2E-0.7-0.05) and cognitive functionality (OR 2.5; 95\% CL 0.94-6.74). However, education (OR 3.1; 95\% CL 1.22-7.92) was the most 


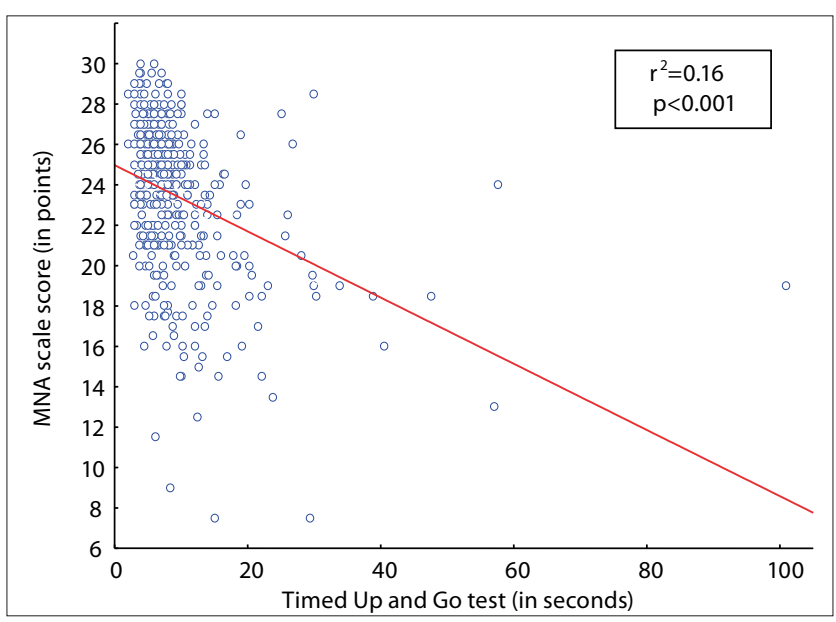

Figure 5. Association between the risk of falls according to the Timed Up and Go test and the nutritional status in the MNA scale

vital factor in socio-demographic terms which contributed to appropriate nutritional status and functional ability. (Table 3).

Table 3. Logistic regression dependent variable MNA

\begin{tabular}{lcc}
\hline Variables & OR & $95 \% \mathrm{CL}$ \\
\hline Education & 3.1 & $1.22-7.92$ \\
\hline MMSE test & 2.5 & $0.94-6.74$ \\
\hline GDS scale & 0.9 & $0.02-0.35$ \\
\hline Time Up \& Go Test & 0.0 & $2 \mathrm{E}-0.7-0.05$ \\
\hline
\end{tabular}

$\mathrm{Chi}^{2}$ goodnes-of-fit test value $(5)=53,591$ where $p=0,00000$

\section{DISCUSSION}

Nutritional status assessment performed within self-study in terms of functional ability involved the elderly living in Poznań city or its vicinity. 5.6\% of subjects presented with malnutrition which amounted to about every 20 th patient. However, the risk of malnutrition was shown in $40 \%$ of patients. The presented difference in the malnutrition prevalence and in the risk of malnutrition development stems from the heterogeneity of the research group, and applies to both the socio-demographic circumstances, health condition, as well as functional ability. Nevertheless, while comparing the obtained data with other published results it is vital to take into account also the tools involved, i.e. the MNA scale. Other tools may be employed in order to assess nutritional status, such as Malnutrition Universal Screening Tool (MUST) questionnaire [22], Nutritional Risk Screening 2002 test [1], Subjective global assessment (SGA) scale [23], or Geriatric Nutritional Risk Index (GNRI) scale [24]. There is no universal recommendation in terms of the elderly subjects.

A mulitparameter analysis of the entire group was performed regarding nutritional status according to the MNA scale and socio-demographic parameters, health condition and functional ability indicators.

In terms of the socio-demographic parameters, it was concluded that malnutrition, as well as the risk of its development, are related to the level of education. Similar results were obtained in Italian research [25]. Other sociodemographic elements point to the fact that the association between age and malnutrition is indirect which may stem from the co-existing diseases and multi-medication in the oldest age groups. In fact, no association between age and nutritional status was confirmed in the course of mulitparameter analysis. What is more, no association was found between the number of administered medications or co-existing diseases and malnutrition, although a number of authors $[4,15,26,27]$ claim that co-existing diseases and multi-medication constitute crucial nutritional status determinants.

In the research group all elements of functional ability influenced the nutritional status, i.e. a deterioration in any element was intertwined with poorer results in the MNA questionnaire. Better nutritional status was characteristic for subjects independent in simple and complex daily activities, with better cognitive function level and decreased risk of depression or falls. However, according to the mulitparameter analysis, the risk of depression and falls, cognitive function and education are independent nutritional status factors, and thus they should be employed in further analyses.

According to both uni-, as well as mulitparameter analysis, the GDS scale result constitutes a paramount nutritional status factor which defines the risk of depression, as the increased risk of depression was associated with a decreased MNA scale result. In fact, it is commonly accepted that depression predisposed the elderly to malnutrition. Furthermore, Smoliner et al. [28], Grieger et al. [29] also point to depression as the most vital causative nutritional status determinant. It was indicated $[27,30,31]$ that depression and general poor mental condition is closely connected to the risk of malnutrition, apart from age and the co-existing chronic disorders. According to other authors [32-37] cognitive function impairment are linked with the risk of malnutrition. In fact, in the research group, both depression and the MNA scale result correlated positively with the cognitive function results according to the MMSE scale. It was established that there exists a "vicious circle" mechanism where malnutrition increases both the risk of depression and cognitive functions impairment, and vice versa. Therefore, on the basis of self-study it is impossible to clearly confirm which variable constitutes the cause and which is the effect, although a clear association between the results in the MNA and MMSE scale was shown.

In the course of analysis it was observed that a group of subjects with nutritional disorders had poorer results both on the Barthel and IADL scales. Moreover, Ülger et al. [37] and Ferdous et al. [32] pointed to the association between basic and instrumental daily activities and nutritional status, stating that it constitutes the most crucial predisposing factor to nutritional status deterioration, apart from depression.

The risk of falls among the elderly constitutes a common issue [12]. The studied group with the risk of falls suffered from nutritional status disorders, and the risk of nutritional status deterioration correlated with the risk of falls in the mulitparameter analysis. Therefore, it constitutes an independent possible nutritional status determinant which was also confirmed by other authors [38]. Normal nutritional status is inextricably intertwined with elderly's functional improvement in all aspects, additionally influencing a decrease in the risk of falls.

The obtained results revealed certain factors which may influence nutritional status disorders and a decrease in functional ability. The abovementioned factors may be 
subsequently involved in the nutritional status monitoring and changes in the abilities. What is more, they suggest a need for devising and the introduction of interdisciplinary interventions for which full geriatric assessment, including nutritional status, constitute the starting point. In addition, it seems necessary to discuss the changes in the elderly on the educational level and develop individual strategies.

\section{CONCLUSIONS}

1. More than half of the respondents had a normal nutritional status and good functional ability.

2. Poor nutritional status was rather rare in subjects who were functionally able; the risk of malnutrition was a more frequent issue.

3. The occurrence of depression, cognitive function ability, education and increased risk of falls in all subjects correlated with nutritional status.

4. This indicates the necessity of performing nutritional status screening assessment in cases of decreased functional ability.

5. It is vital to notice that the association between nutritional status and a decrease in functional ability may be dual, i.e. the functional ability in the elderly presenting poor nutritional status may be decreased; on the other hand, the risk of nutritional issues in patients with decreased functional ability is high. Therefore, further research is necessary for assessing these tendencies.

\section{REFERENCES}

1. Kondrup J, Rasmussen HH, Hamberg O, Stanga Z. Nutritional risk screening (NRS 2002): a new method based on an analysis of controlled clinical trials. Clin Nutr. 2003; 22: 321-336.

2. Ribeiro DKMN, Lenardt MH, Lourenco TM, et al. The use of the functional independence measure in elderly. Rev Gaucha Enferm. 2018; 38(4). doi: 10.1590/1983-1447.2017.04.66496.

3. Forster S, Gariballa S. Age as a determinant of nutritional status: A cross sectional study. Nutr J. 2005; 27: 4-28.

4. Volkert D, Saeglitz C, Gueldenzoph H, et al. Undiagnosed malnutrition and nutrition - related problems in geriatric patients. Nutr Health Aging. 2010; 14: 387-392.

5.Holle R, Gräßel E, Ruckdäschel S, et al. Dementia care initiative in primary practice - study protocol of a cluster randomized trial on dementia management in a general practice setting. Health Serv Res. 2009; 6: 9-91.

6. Feldblum I, German L, Castel H, et al. Characteristics of undernourished older medical patients and the identification of predictors for undernutrition status. Nutr J. 2007; 2: 6-37.

7.Izawa S, Kuzuya M, Okada K, et al. The nutritional status of frail edery with care needs according to the mini-nutritional assessment. Clin Nutr. 2006; 25: 962-967.

8. Risonar MGD, Rayco-Solon P, Ribaya-Mercado JD, et al. Physical activity, energy requirements, and adequacy of dietary intakes of older persons in a rural Filipino community. Nutr J. 2009; 4: 8-19.

9. Marrone A, Donini LM, Scardella P, et al. Malnutrition in eldery: clinical features, psychological and social determinants. Preliminary results. Ann Iq. 2011; 23: 161-172.

10. Dessi M, Noce A, Agnoli A, et al. The usefulness of the prognostic inflammatory and nutritional index (PINI) in a haemodialysis population. Nutr Metab Cardiovasc Dis. 2009; 19, 11: 811-5.

11. Cuervo M, Ansorena D, García A, et al. Assessment of calf circumference as an indicator of the risk for hyponutrition in the elderly. Nutr Hosp. 2009; 24: 63-67.

12. Nakagawa HB, Ferraresi JR, Prata MG, et al. Postural balance and Functional independence of elderly people according to gender and age: cross-sectional study. Sao Paulo Med. 2017; 135(3): 260-265.
13.Lei Z, Qingyi D, Feng G, et al. Clinical study of Mini Nutritional assessment for older Chinese inpatients. J Nutr Health Aging, 2009; 13(10): 871-875.

14. Phillips MB, Foley AL, Barnard R, et al. Nutritional screening in community-dwelling older adults: a systematic literature review. Asia Pac J Clin Nutr. 2010; 19: 440-449.

15. Bauer JM, Sieber CC. Significance and diagnosis of malnutrition in the elderly. Z Arztl Fortbild Qualitatssich. 2007; 101: 605-609.

16. Mahoney FI, Barthel DW. Functional evaluation: the Barthel Index. Md State Med J. 1965; 14: 61-65.

17. Lawton MP, Brody EM. Assessment of older people: self-maintaining and instrumental activities of daily living. Gerontologist. 1969; 9(3): 179-186.

18. Folstein M, Folstein S, McHugh P. Mini-Mental state. a practical method for grading the cognitive state of patients for the clinician. J Psychiatr Res 1975; 12(3): 189-198.

19. Podsiadlo D, Richardson S. The Timed "Up \& Go": A Test of Basic Functional Mobility for Frail Elderly Persons. J Am Geriatr Soc. 1991; 39: 142-148. doi:10.1111/j.1532-5415.1991.tb01616.x

20. Yesavage JA, Brink TL, Rose TL, Lum O, Huang V, Adey MB, Leirer VO. Development and validation of a geriatric depression screening cale: A preliminary report. J Psychiatr Res. 1983; 17: 37-49.

21. Guigoz Y, Vellas B. The Mini Nutritional Assessment (MNA) for Grading the Nutritional State of Elderly Patients: Presentation of the MNA, History and Validation. In: Editor(s): B. Nestle Nutr Workshop Ser Clin Perform Programme. 1999; 1: 3-11.

22. Kondrup J, Allison SP, Elia M. ESPEN guidelines for nutrition screening 2002. Clin Nutr. 2003; 22: 415-421.

23. Sacks GS, Dearman K, Reploge WH. Use of subjective global assessment to identify nutrition-associated complications and death in geriatric long-term care facility residents. J Am Coll Nutr. 2000; 19: 570-577.

24. Phillips MB, Foley AL, Barnard R, et al. Nutritional screening in community-dewelling older adults: a systematic literature review. Asia Pac J Clin Nutr. 2010; 19: 440-449.

25. Timpini A, Facchi E, Cossi S, et al. Self-reported socio-economic status, social, physical and leisure activities and risk for malnutrition in late life: a cross-sectional population-based study. J Nutr Health Aging. 2011; 15: 233-238.

26. Jyrkkä J, Enlund H, Lavikainen P, et al. Association of polypharmacy with nutritional status, functional ability and cognitive capacity over a three-year period in an elderly population. Pharmacoepidemiol Drug Saf. 2011; 20: 514-522.

27. Visvanathan R, Newbury JW, Chapman I. Malnutrition in older people. Screening and management strategies. Aust Fam Phys. 2004; 33: 799-805.

28. Smoliner C, Norman K, Wagner KH, et al. Malnutrition and depression in the institiutionalised elderly. Br J Nutr. 2009; 102: 1663-1667.

29. Grieger JA, Nowson CA, Ackland LM. Nutritional and fuctional status indicators in residents of a long-term care facility. J Nutr Elder. 2009; 28: 47-60.

30. Kaburagi T, Hirasawa R, Yoshino H, et al. Nutritional status in strongly correlated with grip strength and depression in community-living elderly Japanese. Public Health Nutr. 2011; 14: 1893-1899.

31. Isaia G, Mondino S, Germinara C, et al. Malnutrition in an elderly demented population living home. Arch Gerontol Geriatr. 2011; 53: 249-251.

32. Ferdous T, Cederholm T, Kabir ZN, et al. Nutritional status and cognitive function in community-living rural Bangladeshi older adults: data from the poverty and health in ageing project. J Am Geriatr Soc. 2010; 58: 919-924.

33. Johansson L, Sidenvall B, Malmberg B, et al. Who will become malnourished? A prospective study of factors associated with malnutrition in older persons living at home. J Nutr Health Aging. 2009; 13: 855-861.

34. De La Montana J, Miguez M. Suitability of the short-form Mini Nutritional Assessment in free-living elderly people in the northwest of Spain. J Nutr Health Aging. 2011; 15: 187-191.

35. Orsitto G, Fulvio F, Tria D, et al. Nutritional status in hospitalized elderly patients with mild cognitive impairment. Clin Nutr. 2009; 28: 100-102.

36. Oliveira MR, Fogaca KCP, Leandro-Merhi VA. Nutritional status and functional capacity of hospitalized eldery. Nutr J. 2009; 8: 54-62.

37. Ülger Z. Halil M., Kalan I, et al. Comprehensive assessment of malnutrition risk and related factors in a large group of communitydwelling older adults. Clin Nutr. 2010; 29: 507-511.

38. Ghisla MK, Cossi S, Timpini A, et al. Predictors of successful rehabilitation in geriatric patients: subgroup analysis of patients with cognitive impairment. Aging Clin Exp Res. 2007; 19: 417-423. 